\title{
Clare Gerada: We need a complaints code of conduct
}

\author{
Clare Gerada GP partner
}

Hurley Group, London, UK

The number of complaints against NHS staff is rising, possibly resulting (rightly) from better systems and general encouragement to complain if patients have concerns about their care. Complaints increased by $5 \%$ between 2016 and 2017. ${ }^{1}$ I have received my fair share of complaints, and all have affected me personally.

Patients must be able to complain when things have not gone as they should. But a complaint, no matter how trivial, is a powerful trigger for mental illness. A survey of nearly 8000 doctors found that $77 \%$ who had received a complaint were more likely to suffer moderate to severe depression and had twice the risk of moderate to severe anxiety compared to those with no history of a complaint. ${ }^{2}$

It can even be a trigger for suicide. ${ }^{2}$ We can rarely be sure why someone chose to take their own life, but complaints often feature in the narratives of doctors who have done so.

Complaints change doctors' behaviour. They become more cautious and less confident in their practice. ${ }^{3}$ Poorly handled complaints often result in dysfunctional behaviour, such as failure to disclose all events, blaming of self and others, and arguments. This hinders rather than fosters learning after a serious untoward incident or "never event" and can harm future patients, sometimes termed the secondary victims.

\section{Complaints often feature in the narratives of doctors who have taken their own lives}

A serious complaint can take years to pass through the regulatory system, leaving the doctor stuck in a confusing matrix of fear, uncertainty, and anxiety. The complainant has a tried and tested framework that everyone involved-managers, clinicians, organisations-must follow. Those complained about have no similar framework.

I am medical director of the NHS Practitioner Health Programme (PHP), a confidential service for doctors and dentists with issues relating to a mental or physical health concern or addiction problem. At PHP we have worked with healthcare workers and patients (lay and medical) to develop a draft best practice code for handling complaints against doctors. ${ }^{4}$ The code aims to minimise the harm caused by an already stressful process and to ensure a timely and fair response for all parties. It also aims to balance the rights of patients with those of doctors. Although our code is aimed at doctors, the NHS as a whole should be adopting such a code, or something similar.

The code suggests some basic rights: that doctors be given enough time for reflection before having to give statements (in our experience, doctors tend to "over-admit" their failings), and that doctors have a safe space, with workplace support, to discuss the events. Patients could also benefit from better complaints handling, as it should mean a safer, faster, and more open process and, in the end, better learning all round.

It is important that patients have the right to complain when things have not gone well but also that doctors are supported during the process and are treated with the same humanity as the patients they treat.

Organisations need to understand the effect of complaints on a doctor's mental health. Doing so might help reduce the number of doctors affected by mental illness and who go on to take their lives. Adopting a complaints code such as the one PHP is trying to create would help.

Competing interests: I am a former chair of the Royal College of General Practitioners, a partner of the Hurley Group, and shareholder of eConsult. I am also a non-executive director at University College London Hospitals and a member of the General Medical Council's independent inquiry on gross negligence manslaughter.

Provenance and peer review: Commissioned; not externally peer reviewed.

NHS Digital. Data on written complaints in the NHS, 2016-17 - NHS Digital. 2018. https: //digital.nhs.uk/data-and-information/publications/statistical/data-on-written-complaintsin-the-nhs/data-on-written-complaints-in-the-nhs-2016-17.

2 Bourne T, Wynants L, Peters M, etal. The impact of complaints procedures on the welfare, health and clinical practise of 7926 doctors in the UK: a cross-sectional survey. BMJ Open 2015;5:e006687. 10.1136/bmjopen-2014-006687 25592686

3 Bourne T, Vanderhaegen J, Vranken R, etal . Doctors' experiences and their perception of the most stressful aspects of complaints processes in the UK: an analysis of qualitative survey data. BMJ Open 2016;6:e011711. 10.1136/bmjopen-2016-011711 27377638 4 NHS Practitioner Health Programme. Draft code for complaints. http://php.nhs.uk/wpcontent/uploads/sites/26/2018/08/Complaints-.pdf.

Published by the BMJ Publishing Group Limited. For permission to use (where not already granted under a licence) please go to http://group.bmj.com/group/rights-licensing/ permissions 
